\title{
Pertumbuhan Beberapa Jenis Sirih (Piper spp.) pada Berbagai Intensitas Naungan
}

\author{
The Growth of Various Type Betel (Piper spp.) Under Various Shade Intensity
}

\author{
Ain Nur Rahmawati ${ }^{1}$, Ani kurniawati ${ }^{1 *}$ \\ ${ }^{1}$ Departemen Agronomi dan Hortikultura, Fakultas Pertanian, Institut Pertanian Bogor \\ (Bogor Agricultural University), Jl. Meranti, Kampus IPB Darmaga, Bogor 16680, Indonesia \\ Telp. \& Faks.62-251-8629353 e-mail agronipb@indo.net.id \\ *Penulis untuk korespondensi: ani_kurniawati@yahoo.co.id
}

Disetujui 14 November 2016/ Published online 8 Desember 2016

\begin{abstract}
The objective of this research was to determine the effect of shading on growth of some types of piper. The experiment was conducted in Leuwikopo experimental farm of IPB Dramaga, Bogor, on July - October 2014. Nested plot design with two factors (shading percentage and types of piper) and four replications was used in this experiment. There were four levels of shading percentage (0\%, 25\%, 50\%, dan 75\%) and five levels of types piper (Red, Wulung, Green, Golden, and Black). The Result indicated that shading effected on growth of piper. Based of relatif yield, five types of piper were shade plant. The best condition for growth of the five types of piper was $75 \%$ shading.
\end{abstract}

Keywords : antosianine, carotene, piper, shade

\begin{abstract}
ABSTRAK
Percobaan ini dilakukan untuk mengetahui pengaruh naungan terhadap pertumbuhan beberapa jenis sirih yang dilaksanakan di Kebun Percobaan Leuwikopo, Institut Pertanian Bogor pada bulan Juli-Oktober 2014. Percobaan menggunakan rancangan petak tersarang, dua faktor dan empat ulangan. Petak utama yaitu persen naungan yang terdiri dari 4 taraf $(0 \%, 25 \%, 55 \%$, dan $75 \%)$ dan anak petaknya adalah lima jenis sirih yaitu sirih merah, sirih wulung, sirih hijau, sirih golden, dan sirih hitam. Hasil penelitian ini menunjukkan naungan berpengaruh terhadap pertumbuhan sirih. Berdasarkan produksi relatif terhadap kontrol kelima jenis sirih tersebut dapat dikelompokkan menjadi jenis tanaman yang menyukai terhadap naungan. Pertumbuhan lima jenis sirih terbaik terdapat pada taraf naungan $75 \%$.
\end{abstract}

Kata kunci : antosianin, karoten, naungan, sirih 


\section{PENDAHULUAN}

Indonesia memiliki keanekaragaman hayati yang sangat tinggi yang tersebar di berbagai tipe habitat. Hutan tropis Indonesia memiliki sekitar 30 ribu tumbuhan jauh melebihi daerah tropis lainnya seperti Amerika Selatan dan Afrika barat. Diketahui, sekitar 9600 spesies berkhasiat obat dan sekitar 200 spesies diantaranya merupakan tumbuhan obat penting bagi industri obat tradisional (Sampoerno, 1999, Zuhud et al., 2001, Azmy, 2002). Menteri kesehatan dalam laporannya menyebutkan bahwa menurut Organisasi Kesehatan Dunia (WHO) 80\% penduduk dunia bergantung pada pengobatan tradisional, termasuk obat herbal (Depkes, 2009).

Salah satu tumbuhan obat yang telah banyak dikenal khasiat dan kegunaannya adalah sirih (Piper sp.). Tanaman sirih sangat banyak macamnya, berdasarkan warna daunnya tanaman sirih ada yang berwarna hijau, merah, hitam, kuning bahkan ada yang berwarna perak. Sirih merah (Piper crocatum Ruiz and Pav.) banyak diburu orang karena khasiatnya untuk menyembuhkan berbagai jenis penyakit dan sebagai tanaman hias. Tanaman ini memiliki nilai jual tinggi karena penampilannya yang indah khususnya pada bagian daunnya. Tanaman sirih merah merupakan tanaman yang tumbuh merambat di pagar atau pohon. Permukaan daun sirih merah berwarna merah keperakan dan mengkilap saat cahaya menerpa (Sudewo 2005).

Keaneragaman tanaman sirih di Indonesia sangat beragam. Sirih dapat dibedakan berdasarkan warna daun menjadi beberapa jenis yaitu sirih merah sirih wulug dan sirih hijau, sirih golgen, dan sirih hitam. Sirih wulung sering disebut sebagai sirih ungu karena mengeluarkan cahaya berwarna ungu ketika disinari dari bawah pada malam hari. Tanaman ini disebut pula sirih keraton karena sirih wulung konon hanya terdapat di sekitar kawasan keraton Yogyakarta (Ahmad, 2003). Sirih hijau biasanya digunakan untuk berbagai kegiatan adat maupun untuk obat. Sirih golden atau sirih jalu yang mempunyai batik atau bercak kuning pucat, dan sirih hitam yang sering disangkut pautkan dengan dunia mistis.

Peranan cahaya bagi tanaman terlihat jelas dalam proses fotosintesis, cahaya akan ditangkap oleh klorofil untuk menghasilkan fotosintat melalui serangkaian reaksi kimia dan digunakan bagi pertumbuhan tanaman. Hasil fotosintesis digunakan untuk membangun struktur tubuh tanaman. Naungan akan mengurangi intensitas radiasi surya dan berpengaruh terhadap perubahan suhu maksimum, suhu tanah dan kelembaban nisbi. Cahaya dan suhu akan menentukan kegiatan fisiologi, translokasi dan akumulasi asimilat (Gardner et al., 1991).

Pemberian naungan akan memberikan pengaruh yang berbeda untuk jenis sirih yang berbeda. Hasil penelitian Rachmawaty (2005), menunjukkan bahwa jenis pegagan yang berbeda memberikan pengaruh nyata sampai sangat nyata terhadap peubah panjang tangkai daun, jumlah daun, anakan, dan panjang stolon, serta tidak berbeda nyata pada bobot basah dan kering daun, serta pada bobot panen. Hal tersebut memberikan peluang untuk meningkatkan produksi obat dengan memanfaatkan lahan-lahan di bawah naungan yang berpotensi untuk pengembangan tanaman sirih sehingga nantinya akan diperoleh spesies tanaman sirih yang adaptif dan berproduksi tinggi pada kondisi lahan di bawah naungan

Penelitian ini bertujuan untuk mempelajari pegaruh tingkat naungan terhadap pertumbuhan dan produksi daun pada berbagai jenis sirih yaitu sirih merah, sirih wulung, sirih hitam, sirih hijau, dan sirih golden.

\section{BAHAN DAN METODE}

Penelitian dilaksanakan pada bulan Juni hingga Oktober 2014 di Kebun Percobaan IPB Leuwikopo, Dramaga Bogor. Analisis klorofil dan kerapatan stomata di Laboratorium Micro Technique Marker and Spectrophotometry UVVIS. Analisis fitokimia di Laboratorium Kimia Analitik IPB. Bahan utama yang digunakan dalam penelitian ini adalah stek sirih merah, sirih wulung, sirih hijau, sirih golden, dan sirih hitam. Media tanam yang digunakan berupa tanah, serasah bambu dan pupuk kandang serta furadan. Alat-alat yang digunakan adalah alat budidaya pertanian secara umum, polibag, jangka sorong, penggaris atau meteran, label, katalog cat, ajir, dan alat tulis. Untuk naungan digunakan paranet $25 \%, 55 \%$, dan $75 \%$.

Penelitian ini disusun dalam rancangan petak tersarang yang terdiri dari dua faktor. Petak utama adalah aplikasi naungan yang terdiri dari 4 taraf yaitu tanpa naungan $0 \%$, naungan $25 \%$, naungan $55 \%$, dan naungan $75 \%$. Anak petak adalah lima jenis sirih yang terdiri dari sirih merah, sirih wulung, sirih hijau, sirih golden, dan sirih hitam. Setiap perlakuan dilakukan sebanyak empat ulangan sehingga terdapat 80 satuan percobaan, tiap satuan percobaan terdiri enam tanaman, sehingga digunakan 480 tanaman. Pengolahan data dilakukan dengan uji $t$ - student pada taraf 5\%. Apabila signifikan dilanjutkan dengan uji Dunnett pada taraf 5\% untuk mengetahui perbedaan antar perlakuan. 
Bahan tanam di dapat dari Bagas Florist, Sukamantri Tamansari - Bogor. Pembibitan dilakukan dengan stek batang sirih yang tua dipotong sepanjang $\pm 10 \mathrm{~cm}$ atau dua ruas yang berdaun satu hingga dua ruas dengan media tanam berupa lumpur dan serasah daun bambu dengan perbandingan $3: 1$ pada polibag diameter $10 \mathrm{~cm}$. Luas lahan yang digunakan adalah $\pm 172 \mathrm{~m}^{2}$, dibuat menjadi empat petakan sesuai perlakuan. Setiap petakan dibuat bedeng dengan ditinggikan $\pm 30 \mathrm{~cm}$. Dalam tiga petakan digunakan paranet sesuai perlakuan, setiap ujung dibuat tiang penyangga dari bambu dengan ketinggian $2 \mathrm{~m}$. Penanaman bibit dipindahkan setelah bibit berdaun tiga hingga empat dengan media tanam tanah, serasah bambu, dan pupuk kandang dengan perbandingan 2:1:1 pada polibag berdiameter 30 $\mathrm{cm} \times 20 \mathrm{~cm}$. Kegiatan pemeliharaan meliputi penyulaman (hingga 2 MST), penyiangan dan pengendalian hama penyakit tanaman bila diperlukan. Penyiraman dilakukan setiap hari selama masa penelitian. Pada polibag yang sudah ditanami juga diberikan ajir setinggi $\pm 1 \mathrm{~m}$ untuk menyangga dan melilitkan tanaman. Pertumbuhan tanaman yang diamati yaitu tinggi tanaman, diameter batang, jumlah daun dan jumlah buku. Karakter morfologi dan fisiologi yang diamati yaitu jumlah klorofil, jumlah trikoma, kerapatan stomata, uji fitokimia, ketebalan daun, dan warna daun.

\section{HASIL DAN PEMBAHASAN}

\section{Kondisi Umum}

Penelitian ini dilaksanakan mulai Juni sampai Oktober 2014, dengan curah hujan ratarata $254.6 \mathrm{~mm} / \mathrm{bulan}$. Curah hujan tertinggi terdapat pada bulan Oktober 2014 yaitu sebesar $347 \mathrm{~mm}$. Curah hujan terendah terdapat pada bulan Agustus. Berdasarkan data Stasiun Klimatologi BMKG Dramaga 2014, selama penelitian intensitas cahaya rata-rata yaitu sebesar $248.5 \mathrm{cal} \mathrm{cm}^{-2}$. Intensitas cahaya tertinggi terjadi pada bulan September 2014 sebesar $285 \mathrm{cal} \mathrm{cm}^{-2}$ dan yang terendah pada bulan Juni 2014 sebesar $198 \mathrm{cal} \mathrm{cm}^{-2}$. Suhu lokasi penelitian rata-rata selama lima bulan yaitu sebesar $26.22{ }^{\circ} \mathrm{C}$, suhu tertinggi pada bulan Oktober 2014 dan suhu terendah pada bulan Agustus 2014.

Hama dan penyakit yang ditemui pada penelitian ulat grayak (Spodoptera litura), walang sangit, belalang, siput, semut, bercak daun (Alternaria solani), serta daun yang layu atau gosong terbakar cahaya matahari.

Berikut ini adalah hasil identifikasi atau determinasi dari "Herbarium Bogoriense", Bidang
Botani Pusat Penelitian Biologi-LIPI Bogor (Tabel 1). Menurut Tri (2011) dan Tarun et al. (2012) sirih hitam mempunyai nama ilmiah Piper Betle var nigra dan tergolong kedalam suku atau famili Piperaceae.

Tabel 1. Identifikasi Bidang Botani Pusat Penelitian Biologi - LIPI Bogor

\begin{tabular}{lll}
\hline Jenis Sirih & Nama Latin & Famili \\
\hline Wulung & Piper crocatum Ruiz \& Pav. Piperaceae \\
Golden & Piper crocatum Ruiz \& Pav. Piperaceae \\
Hitam & Piper crocatum Ruiz \& Pav. Piperaceae \\
\hline sumber: Bidang Botani Pusat Penelitian Biologi-LIPI Bogor
\end{tabular}
(2014)

Rekapitulasi tanaman yang hidup ini untuk mengetahui jumlah tanaman yang diamati selama pengamatan. Tanaman yang mati pada MST ke-1 dan MST ke-2 akan disulam dengan tanaman yang baru, dan untuk MST seterusnya tidak disulam. Untuk perlakuan tanpa naungan sirih wulung dan sirih hitam banyak tanaman yang mati hingga MST ke -12. Untuk naungan 55\% dan $75 \%$ dari awal pengamatan tidak ada tanaman yang disulam. Sirih hijau dan sirih golden merupakan tanaman yang lebih sedikit mati dibandingan dengan jenis sirih yang lain.

Tabel 2. Persentase tumbuh tanaman sirih

\begin{tabular}{cccccc}
\hline $\begin{array}{c}\text { Naungan } \\
(\%)\end{array}$ & \multicolumn{5}{c}{ Prosentase jenis sirih (\%) } \\
\cline { 2 - 6 } & Merah & Wulung & Hijau & Golden & Hitam \\
\hline 0 & 17 & 5 & 87 & 87 & 25 \\
25 & 71 & 67 & 75 & 63 & 55 \\
55 & 88 & 55 & 100 & 75 & 87 \\
75 & 71 & 75 & 96 & 100 & 59 \\
\hline
\end{tabular}

Pengaruh Naungan terhadap Pertumbuhan Tanaman

Tinggi tanaman. Tinggi tanaman dipengaruhi oleh taraf naungan terlihat dari adanya pengaruh yang sangat nyata pada perlakuan dan setiap waktu pengamatan. Tinggi tanaman yang ditanam pada taraf naungan $25 \%, 50 \%$, dan $75 \%$ menunjukkan tinggi tanaman yang maksimum pada umur 12 MST. Tinggi tanaman tertinggi terdapat pada taraf naungan $75 \%$ yaitu $29.22 \mathrm{~cm}$ (Tabel 3).

Hal ini sesuai dengan pengaruh naungan terhadap tinggi tanaman padi gogo memperlihatkan bahwa terjadi peningkatan tinggi tanaman dengan semakin meningkatnya naungan (Riyadi, 1999), namun pada naungan 25\% dan $55 \%$ tinggi tanaman menurun kembali. Pada awal pertumbuhan, tinggi tanaman tertinggi terjadi pada jenis sirih wulung, namun pada 7MST tinggi tanaman tertinggi terjadi pada jenis sirih hijau. 
Salisbury dan Ross (1995) menyatakan bahwa tanaman yang terkena banyak naungan akan mengalami pemanjangan sel, khususnya pada batang. Hal ini terjadi karena produksi auksin pada pucuk meningkat dan ditranslokasikan secara basipetal yang akan merangsang pemanjangan sel tanaman. Peningkatan tinggi tanaman pada kondisi ternaungi digunakan tanaman untuk meningkatkan efisiensi penyerapan cahaya dan memperbanyak jumlah cahaya yang diserap.

Tabel 3. Pengaruh naungan dan jenis sirih terhadap tinggi tanaman

\begin{tabular}{|c|c|c|c|c|c|}
\hline Perlakuan & $4 \mathrm{MST}$ & $6 \mathrm{MST}$ & $8 \mathrm{MST}$ & $10 \mathrm{MST}$ & $12 \mathrm{MST}$ \\
\hline Naungan $(\%)$ & \multicolumn{5}{|c|}{------------------------cm---------------------- } \\
\hline $0-25$ & $4.82 *$ & $12.32 * *$ & $19.36^{* *}$ & $22.45 * *$ & $20.74 * *$ \\
\hline $0-55$ & $10.10 * *$ & $16.06 * *$ & $22.97 * *$ & $24.96 * *$ & $24.92 * *$ \\
\hline $0-75$ & $11.49 * *$ & $18.87 * *$ & $23.63 * *$ & $26.51 * *$ & $29.22 * *$ \\
\hline $25-55$ & $3.28 * *$ & 3.74 & 3.41 & 2.51 & 4.18 \\
\hline $25-75$ & $6.66 * *$ & $6.35 *$ & 4.07 & 4.06 & 8.48 \\
\hline $55-75$ & 1.38 & 2.81 & 0.66 & 1.33 & 4.31 \\
\hline \multicolumn{6}{|l|}{ Jenis sirih } \\
\hline Merah - Wulung & 10.75 & 9.03 & 9.00 & 8.90 & 6.20 \\
\hline Merah - Hijau & 6.88 & 9.05 & 16.36 & $22.51 *$ & $25.78 *$ \\
\hline Merah - Golden & 3.10 & 7.43 & 12.86 & 16.03 & 12.7 \\
\hline Merah - Hitam & 2.04 & 5.37 & 6.73 & 6.73 & 7.64 \\
\hline Wulung - Hijau & 3.87 & 0.02 & 7.38 & 13.60 & 19.50 \\
\hline Wulung - Golden & 7.64 & 1.60 & 3.90 & 7.10 & 6.30 \\
\hline Wulung - Hitam & 12.79 & 14.40 & 13.71 & 15.70 & 13.90 \\
\hline Hijau - Golden & 3.77 & 1.62 & 3.70 & 6.48 & 13.06 \\
\hline Hijau - Hitam & $8.92 *$ & 14.42 & $23.29 * *$ & $29.24 * *$ & $33.42 * *$ \\
\hline Golden - Hitam & 5.14 & 12.80 & 19.60 & 22.76 & 20.36 \\
\hline
\end{tabular}

Diameter batang. Tabel 4 menunjukkan pada semua pengamatan diameter batang terbesar diperoleh pada naungan $75 \%$. Lima jenis sirih yang diuji mempunyai ukuran diameter batang yang berbeda. Pada umur 12MST diameter yang terendah ditunjukkan oleh jenis sirih hijau sebesar $0.06 \mathrm{~cm}$ terhadap sirih wulung.Berdasarkan penelitian Ekawati (2009) pengaruh naungan pada tanaman Sambung Nyawa sangat nyata terhadap diameter batang, nyata terhadap variable panjang daun, lebar daun, dan panjang tangkai daun. Diameter, panjang daun, lebar daun, dan panjang tangkai daun di lahan ternaungi lebih besar daripada di lahan tanpa naungan.

Jumlah daun. Jumlah daun pada perbandingan taraf naungan 25-0\% memiliki nilai yang terendah dibandingkan dengan perbandingan taraf naungan yang lainnya dan yang terbanyak terdapat pada perbandingan taraf naungan $75-0 \%$ (Tabel 5). Penurunan jumlah daun perbandingan taraf naungan 25-55 \% dan 25-75 \% 8MST disebabkan tumbuhan menggunakan energi lebih banyak untuk meningkatkan tinggi tanaman akibat proses etiolasi.

Penurunan jumlah daun naungan 25\% 10 MST disebabkan tumbuhan menggunakan energi lebih banyak untuk meningkatkan tinggi tanaman akibat proses etiolasi. Daun yang berada dalam kondisi ternaungi akan mengalami penuaan yang lebih cepat dan akibatnya daun tidak menyumbang fotosintat bersih sehingga laju pertumbuhan vegetatif terhambat dan jumlah daun pada tanaman menjadi berkurang (Goldsworthy dan Fisher, 1992).

Jumlah daun terbanyak pada 12 MST terdapat pada jenis sirih hijau sebanyak 6.50 buah dan jumlah daun terendah jenis sirih wulung sebesar 3.65 buah. Berdasarkan penelitian Musyarofah et al. (2007) Jumlah daun, jumlah stolon dan panjang tangkai daun terpanjang dari tanaman pegagan pada naungan 55\% lebih tinggi dibandingkan dengan tanaman pada naungan 65 dan $75 \%$. 
Bul. Agrohorti 4(3): 288-297 (2016)

Tabel 4. Pengaruh naungan dan jenis sirih terhadap diameter batang

\begin{tabular}{|c|c|c|c|c|c|c|}
\hline Perlakuan & $2 \mathrm{MST}$ & $4 \mathrm{MST}$ & $6 \mathrm{MST}$ & $8 \mathrm{MST}$ & $10 \mathrm{MST}$ & $12 \mathrm{MST}$ \\
\hline Naungan (\%) & \multicolumn{6}{|c|}{ |-----------------------cm----------------------- } \\
\hline $0-25$ & 0.08 & $1.14^{* *}$ & $1.16^{* *}$ & $1.23 * *$ & $1.23 * *$ & $1.12 * *$ \\
\hline $0-55$ & 0.006 & $0.92 * *$ & $1.05^{* *}$ & $1.13 * *$ & $1.23 * *$ & $1.20 * *$ \\
\hline $0-75$ & 0.08 & $0.92 * *$ & $1.09 * *$ & $1.17 * *$ & $1.25 * *$ & $1.36 * *$ \\
\hline $25-55$ & 0.07 & 0.22 & 0.12 & 0.10 & 0.003 & 0.08 \\
\hline $25-75$ & 0.15 & 0.21 & 0.07 & 0.06 & 0.02 & 0.23 \\
\hline $55-75$ & 0.08 & 0.003 & 0.04 & 0.04 & 0.02 & 0.15 \\
\hline Merah - Wulung & $0.99 * *$ & 0.63 & 0.62 & 0.57 & 0.53 & 0.51 \\
\hline Merah - Hijau & 0.28 & 0.39 & 0.31 & 0.51 & 0.59 & 0.57 \\
\hline Merah - Golden & $0.84 * *$ & 1.03 & $1.20 *$ & $1.08 *$ & $1.31 *$ & 0.82 \\
\hline Merah - Hitam & 0.20 & 0.30 & 0.34 & 0.31 & 0.37 & 0.39 \\
\hline Wulung - Hijau & $0.71 * *$ & 0.24 & 0.11 & 0.06 & 0.06 & 0.06 \\
\hline Wulung - Golden & 0.15 & 0.40 & 0.38 & 0.31 & 0.78 & 0.31 \\
\hline Wulung - Hitam & $0.79 * *$ & 0.93 & 0.94 & 0.88 & 0.90 & 0.90 \\
\hline Hijau - Golden & $0.37 * *$ & $0.64 *$ & $0.70 *$ & $0.57 *$ & 0.72 & 0.24 \\
\hline Hijau - Hitam & 0.08 & 0.69 & 0.85 & 0.82 & $0.94 *$ & $0.96^{*}$ \\
\hline Golden - Hitam & $0.64 * *$ & $1.33 *$ & $1.54 *$ & $1.39 *$ & $1.68 * *$ & $1.20 *$ \\
\hline
\end{tabular}

Keterangan: angka - angka pada kolom yang diikuti dengan tanda * menunjukkan perbedaan yang signifikan pada taraf $5 \%$ uji t-student

Tabel 5. Pengaruh naungan dan jenis sirih terhadap jumlah daun

\begin{tabular}{|c|c|c|c|c|c|c|}
\hline Perlakuan & 2 MST & $4 \mathrm{MST}$ & $6 \mathrm{MST}$ & $8 \mathrm{MST}$ & $10 \mathrm{MST}$ & $12 \mathrm{MST}$ \\
\hline \multicolumn{7}{|l|}{ Naungan (\%) } \\
\hline $0-25$ & $1.25 * *$ & $2.08 * *$ & $2.61 * *$ & $3.42 * *$ & $3.43 * *$ & $2.17 * *$ \\
\hline $25-55$ & $1.23 * *$ & $2.62 * *$ & $3.33 * *$ & $3.72 * *$ & $4.13 * *$ & $4.40 * *$ \\
\hline $55-75$ & $1.20 * *$ & $2.54 * *$ & $3.31 * *$ & $4.21 * *$ & $3.06 * *$ & $3.733 * *$ \\
\hline $25-55$ & 0.02 & 0.33 & 0.73 & 0.30 & 0.70 & $1.68 *$ \\
\hline $25-75$ & 0.50 & 0.48 & 0.90 & 0.80 & $1.63 *$ & $3.00 * *$ \\
\hline $55-75$ & 0.03 & 0.08 & 0.18 & 0.50 & 0.93 & 1.32 \\
\hline \multicolumn{7}{|l|}{ Jenis Sirih } \\
\hline Merah - Wulung & $1.71 *$ & 1.03 & 0.90 & 0.21 & 0.31 & 1.27 \\
\hline Merah - Hijau & $1.18^{*}$ & 1.68 & 2.38 & 2.76 & 2.58 & 2.45 \\
\hline Merah - Golden & 0.68 & 1.14 & 2.14 & 2.79 & 2.43 & 1.96 \\
\hline Merah - Hitam & 0.32 & 0.33 & 0.48 & 0.94 & 0.83 & 1.11 \\
\hline Wulung - Hijau & 0.53 & 0.65 & 1.68 & 2.33 & 3.09 & 3.72 \\
\hline Wulung - Golden & 1.02 & 0.11 & 1.23 & 2.38 & 2.94 & 3.23 \\
\hline Wulung - Hitam & 1.38 & 1.37 & 1.38 & 1.15 & 0.32 & 0.17 \\
\hline Hijau - Golden & 0.50 & 0.53 & 0.44 & 0.03 & 0.16 & 0.49 \\
\hline Hijau - Hitam & 0.83 & $2.01 *$ & $3.06 *$ & $3.70 *$ & 3.42 & 3.55 \\
\hline Golden - Hitam & 1.49 & $1.48 *$ & $2.62 *$ & $3.73 *$ & 3.26 & 3.06 \\
\hline
\end{tabular}

Keterangan: angka - angka pada kolom yang diikuti dengan tanda * menunjukkan perbedaan yang signifikan pada taraf $5 \%$ uji tstudent

Jumlah buku. Jumlah buku pada perbandingan taraf naungan $0 \%$ memiliki nilai yang terendah dibandingkan dengan perbandingan taraf naungan yang lainnya dan yang terbanyak terdapat pada perbandingan taraf naungan $75 \%$ (Tabel 8). Pada 12MST jumlah buku terbanyak terdapat pada perbandingan jenis sirih hijau signifikan terhadap sirih hitam sebanyak 8.42 buku dan jumlah buku terendah pada perbandingan tidak signifikan antara jenis sirih merah terhadap sirih wulung sebesar 0.62 buku. 
Tabel 6. Pengaruh naungan dan jenis sirih terhadap jumlah buku

\begin{tabular}{|c|c|c|c|c|c|c|}
\hline Perlakuan & 2MST & 4MST & $6 \mathrm{MST}$ & $8 \mathrm{MST}$ & $10 \mathrm{MST}$ & 12MST \\
\hline \multicolumn{7}{|l|}{ Naungan $(\%)$} \\
\hline $0-25$ & 0.26 & $2.52 *$ & $3.22 *$ & $4.24 *$ & $3.47 *$ & $3.44 *$ \\
\hline $0-55$ & 0.76 & 2.36 & $3.92 *$ & $4.38^{*}$ & $6.64 *$ & $7.30 *$ \\
\hline $0-75$ & 1.16 & $2.65^{*}$ & $4.15^{*}$ & $4.94 *$ & $6.98 *$ & $9.31 * *$ \\
\hline $25-55$ & 0.50 & 0.16 & 0.70 & 0.34 & 1.18 & 2.06 \\
\hline $25-75$ & 0.90 & 0.13 & 0.93 & 0.70 & 1.52 & 3.87 \\
\hline $55-75$ & 0.40 & 0.30 & 0.23 & 0.36 & 0.34 & 1.81 \\
\hline \multicolumn{7}{|l|}{ Jenis sirih } \\
\hline Merah - Wulung & $2.37 * *$ & 1.04 & 1.20 & 0.74 & 0.14 & 0.62 \\
\hline Merah - Hijau & $0.74 * *$ & 2.08 & $3.57 *$ & $4.36^{*}$ & 3.53 & 6.60 \\
\hline Merah - Golden & $0.10^{* *}$ & 1.23 & 2.39 & 3.43 & 4.19 & 3.30 \\
\hline Merah - Hitam & $0.03 * *$ & 0.81 & 0.55 & 0.91 & 1.31 & 1.81 \\
\hline Wulung - Hijau & $1.64 * *$ & 1.04 & 2.37 & 3.61 & 5.39 & 7.22 \\
\hline Wulung - Golden & $2.27 * *$ & 0.19 & 1.40 & 2.69 & 4.05 & 4.11 \\
\hline Wulung - Hitam & $2.41 * *$ & 1.86 & 1.73 & 1.65 & 1.43 & 1.20 \\
\hline Hijau - Golden & $0.63 * *$ & 0.85 & 0.97 & 0.93 & 1.34 & 3.11 \\
\hline Hijau - Hitam & $0.77 * *$ & $2.90 *$ & 4.12 & $5.26^{*}$ & $6.85^{*}$ & $8.42 *$ \\
\hline Golden - Hitam & $0.14 * *$ & 2.04 & 3.15 & $4.33^{*}$ & $5.50 *$ & 5.31 \\
\hline
\end{tabular}

Keterangan: angka - angka pada kolom yang diikuti dengan tanda * menunjukkan perbedaan yang signifikan pada taraf 5\% uji t-student

\section{Pengaruh Naungan terhadap Morfologi dan Fisiologi Tanaman}

Jumlah klorofil. Semakin besar taraf naungan, maka jumlah klorofil semakin banyak. Jumlah klorofil total terbanyak terdapat pada perbandingan naungan 75-0 \% (Tabel 7). Jenis sirih yang paling banyak mengandung klorofil adalah sirih merah yaitu sebesar $2.26 \mathrm{mg} \mathrm{g}^{-1}$.
Kandungan karoten paling banyak terdapat pada perbandingan tanaman taraf 75-0 \% yaitu selisih $0.08 \mathrm{mg} \mathrm{g}^{-1}$ terhadap kontrol. Kandungan antosianin perlakuan naungan tidak signifikan tetapi pada jenisnya sirih wulung dan sirih hitam signifikan terhadap sirih merah (Tabel 7). Klorofil yang lebih banyak ini berkaitan dengan lebih banyak grana yang terbentuk pada daun ternaung dibandingkan pada daun matahari (Lakitan, 2008).

Tabel 7. Pengaruh naungan dan jenis sirih terhadap jumlah klorofil

\begin{tabular}{|c|c|c|c|c|c|}
\hline Perlakuan & Klorofil A & Klorofil B & Antosianin & Karoten & Total klo \\
\hline Naungan $(\%)$ & \multicolumn{5}{|c|}{ 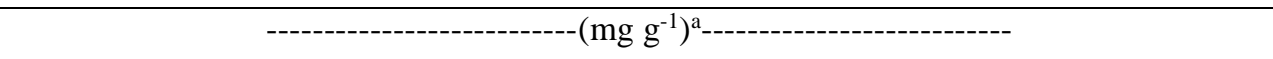 } \\
\hline $0-25$ & 0.09 & 0.03 & 0.01 & 0.06 & 0.12 \\
\hline $0-55$ & 0.02 & 0.01 & 0.02 & 0.04 & 0.03 \\
\hline $0-75$ & 0.24 & 0.12 & 0.01 & 0.08 & 0.35 \\
\hline $25-55$ & 0.11 & 0.43 & 0.01 & 0.05 & 0.15 \\
\hline $25-75$ & 0.15 & 0.08 & 0.02 & 0.07 & 0.23 \\
\hline $55-75$ & 0.26 & 0.13 & 0.03 & 0.12 & 0.38 \\
\hline \multicolumn{6}{|l|}{ Jenis sirih } \\
\hline Merah - Wulung & $0.85 * *$ & $0.37 * *$ & $0.07 * *$ & $0.24 * *$ & $1.22 * *$ \\
\hline Merah - Hijau & $0.73 * *$ & $0.33 * *$ & $0.04 *$ & $0.20 * *$ & $1.06^{* *}$ \\
\hline Merah - Golden & $0.75 * *$ & $0.26 * *$ & $0.05^{*}$ & 0.01 & $1.02 * *$ \\
\hline Merah - Hitam & $0.42 *$ & $0.21 *$ & $0.09 * *$ & $0.13^{*}$ & $0.62 *$ \\
\hline Wulung - Hijau & 0.12 & 0.04 & $0.11 * *$ & 0.04 & 0.16 \\
\hline Wulung - Golden & 0.09 & $0.11^{*}$ & 0.02 & $0.24 *$ & 0.21 \\
\hline Wulung - Hitam & 0.43 & $0.17 *$ & $0.14 * *$ & $0.10^{*}$ & $0.60 *$ \\
\hline Hijau - Golden & 0.02 & 0.07 & $0.09 * *$ & $0.20^{*}$ & 0.05 \\
\hline Hijau - Hitam & 0.31 & 0.13 & $0.04 *$ & 0.06 & 0.44 \\
\hline Golden - Hitam & 0.34 & 0.05 & $0.14 * *$ & 0.13 & 0.39 \\
\hline
\end{tabular}

Daun tanaman pada keadaan ternaungi menggunakan lebih banyak energi untuk menghasilkan pigmen pemanen cahaya yang memungkinkannya mampu menggunakan semua 
cahaya dalam jumlah terbatas yang mengenainya (Salisbury dan Ross, 1995). Antosianin merupakan pigmen yang paling penting dan tersebar luas dalam tumbuhan, digunakan sebagai pembentuk dasar pigmen merah, ungu dan biru pada tanaman, terutama sebagai ewarna bunga dan buah-buahan (Siska, 2011). Terbukti dengan hasil kandungan antosianin pada sirih wulung lebih banyak dibanding dengan sirih yang lain.

Jumlah trikoma. Pengamatan jumlah trikoma yang diamati pada tulang daun, daun sisi atas dan daun sisi bawah. Trikoma hanya terdapat di jenis sirih hitam pada naungan taraf $0 \%$ di tulang daun dan jenis sirih wulung pada naungan taraf $75 \%$ di daun sisi bawah yang masing-masing sejumlah 19 luas bidang pandang dan 13 luas bidang pandang, sedangkan di bagian daun sisi atas tidak dijumpai trikoma.

Menurut Johnnson dalam Gandasari (1994) trikoma berasal dari jaringan epidermal yang kemudian di dalam pertumbuhannya mengalami proses diferensiasi atau pembagian sel sehingga dihasilkan perpanjangan rambut. Trikoma juga merupakan bentuk adaptasi struktural tumbuhan terhadap kekeringan, berfungsi juga sebagai pelindung fisik dan reflektor cahaya. Oleh sebab itu terdapat hubungan positif antara jumlah trikoma dan kadar minyak (Wiroatmodjo et al., 1990).

Kerapatan stomata. Menurut Sundari et al. (2008) jumlah stomata kacang hijau pada perlakuan tanpa naungan nyata lebih banyak dibandingkan dengan perlakuan naungan $52 \%$. Pada jenis sirih golden, kerapatan stomata pada taraf tanpa naungan menunjukkan perbedaan yang nyata dibandingkan dengan taraf naungan yang lainnya. Taraf naungan $75 \%$ sebesar $127.27 \mathrm{~mm}^{2}$ menurunkan kerapatan stomata secara nyata dibandingkan dengan kontrol. Kerapatan stomata jenis sirih hitam pada taraf $25 \%$ dan $75 \%$ menunjukkan perbedaan yang nyata terhadap kontrol (Tabel 8). Penurunan kerapatan stomata tersebut disebabkan oleh kurangnya penguapan air atau nitrogen. Adanya pelebaran porus stomata sangat erat hubungannya dengan transpirasi tumbuhan dalam beradaptasi terhadap lingkungan.

Daerah yang panas menyebabkan stomata harus mengurangi lebarnya guna mengurangi penguapan air, sebaliknya pada daerah teduh stomata lebih membuka (Sri Haryanti, 2010). Menurut Jumin (1992) suhu tinggi atau daerah panas menjebak tanaman kekurangan air dan juga akan kekurangan nitrogen.
Tabel 8. Interaksi naungan dengan jenis sirih terhadap kerapatan stomata

\begin{tabular}{lc}
\hline \multicolumn{1}{c}{ Perlakuan } & $\begin{array}{c}\text { Kerapatan } \\
\text { stomata }\left(\mathrm{mm}^{2}\right)\end{array}$ \\
\hline Naungan (\%) / Jenis sirih & \\
0 / Wulung - 0 / Merah & $75.32 \pm 22.14$ \\
0 / Hijau - 0 / Merah & $145.45 \pm 47.99^{*}$ \\
0 / Golden - 0 / Merah & $168.83 \pm 71.37^{*}$ \\
0 / Hitam - 0 / Merah & $80.52 \pm 16.95$ \\
25 / Merah - 0 / Merah & $46.75 \pm 50.71$ \\
25 / Wulung - 0 / Merah & $106.49 \pm 9.03^{*}$ \\
25 / Hijau - 0 / Merah & $122.08 \pm 24.61^{*}$ \\
25 / Golden - 0 / Merah & $106.49 \pm 9.03^{*}$ \\
25 / Hitam - 0 / Merah & $23.38 \pm 74.09$ \\
55 / Merah - 0 / Merah & $59.74 \pm 37.72$ \\
55 / Wulung - 0 / Merah & $93.46 \pm 4.01$ \\
55 / Hijau - 0 / Merah & $75.32 \pm 22.14$ \\
55 / Golden - 0 / Merah & $137.66 \pm 40.20^{*}$ \\
55 / Hitam - 0 / Merah & $59.74 \pm 37.72$ \\
75 / Merah - 0 / Merah & $57.14 \pm 40.32$ \\
75 / Wulung - 0 / Merah & $127.27 \pm 29.81^{*}$ \\
75 / Hijau - 0 / Merah & $122.08 \pm 24.61^{*}$ \\
75 / Golden - 0 / Merah & $90.91 \pm 6.56$ \\
75 / Hitam - 0 / Merah & $51.95 \pm 45.52$ \\
\hline Keterangan: angka - angka pada kolom yang diikuti dengan \\
\multicolumn{1}{c}{ tanda * menunjukkan perbedaan signifikan } \\
\multicolumn{1}{c}{ pada taraf 5\% uji t-student } \\
\end{tabular}

Uji fitokimia. Uji fitokimia ini dilakukan untuk mengetahui kandungan senyawa yang terkandung dalam kelima jenis sirih. Hasil analisis kandungan senyawa pada berbagai macam tanaman sirih terdapat pada Tabel 9 .

Hasil pengujian menunjukkan bahwa tidak ada perbedaan yang nyata antar taraf naungan tetapi pada kelima jenis sirih menunjukkan hasil yang nyata. Rebusan sirih merah segar tidak mengandung alkaloid, fenolhidrokuinol, dan triterpenoid (Tabel 9). Kelima jenis sirih tidak menunjukkan adanya kandungan alkoloid. Sirih wulung memiliki kandungan tanin yang banyak dari kelima jenis sirih yang diuji, dan hanya sirih wulung yang memiliki kandungan triterpenoid. Hasil uji fitokimia ini tidak jauh berbeda dengan hasil penelitian Andayani (dalam Cahyani et al., 2006) yang menyimpulkan bahwa SM (sirih merah) kaya flavonoid, senyawa folifenat, tanin dan minyak atsiri. Tetapi pengujian ini tidak sesuai dengan pernyataan Agus (2006) karena pada uji alkaloid sirih merah menunjukkan hasil positif terhadap ketiga pereaksi (Wagner, Mayer, dan Dragendorf). Dari ketiga senyawa tersebut (alkaloid, flavonoid, dan tanin), alkaloid, dan flavonoid merupakan senyawa aktif bahan alam yang telah diteliti memiliki aktivitas hipoglikemia (Ivorra et al., 1989 dalam Maryuni, 2002). Sedangkan tanin berfungsi sebagai antioksidan dan penghambat pertumbuhan tumor 
Tabel 9. Hasil Uji Fitokimia pada naungan dan jenis sirih

\begin{tabular}{lcccccc}
\hline \multirow{2}{*}{ Uji } & \multicolumn{5}{c}{ Jenis sirih } \\
\cline { 2 - 6 } & Merah & Wulung & Hijau & Golden & Hitam \\
\hline Alkoloid & - & - & - & - & - \\
Phenol & & + & ++ & ++ & + \\
hidrokuinon & - & ++ & + & & \\
Flavonoid & ++ & +++ & ++ & ++ & ++ \\
Tanin & ++ & ++++ & ++ & +++ & ++ \\
Saponin & ++ & + & + & + & + \\
Steroid & +++ & + & ++ & ++ & + \\
Triterpenoid & - & ++ & - & - & - \\
\hline Keterangan: & - tidak & ada kandungan & $+=$ & ada & sedikit \\
& kandungan & $++=$ ada & kandungan & $+++=$ banyak \\
& kandungan & \multicolumn{7}{l}{}
\end{tabular}

Ketebalan daun. Berdasarkan sidik ragam naungan berpengaruh nyata terhadap ketebalan daun lima jenis sirih. Kondisi ternaungi ketebalan daun sirih menjadi lebih tipis dibandingkan dengan kontrol. Makin tinggi tingkat naungan makin tipis ketebalan daun sirih. Taiz dan Zeiger (1991) menyatakan bahwa daun tanaman ternaungi lebih tipis dan lebih lebar daripada daun pada tanaman yang ditanam pada daerah terbuka, disebabkan oleh pengurangan lapisan palisade dan sel-sel mesofil.

Rata-rata ketebalan daun sirih pada keadaan tanpa naungan (kontrol) adalah signifikan dengan perlakuan naungan $75 \%$ dengan selisih $5.74 \mu \mathrm{m}$ lebih tebal pada perlakuan tanpa naungan. Tanaman jenis sirih hijau memiliki ketebalan daun sirih yang lebih tipis dibandingkan dengan jenis sirih hitam yang lebih tebal dengan selisih $\mu \mathrm{m}$ (Tabel 10). Menurut Musyarofah et al. (2007) pada tanaman pegagan, ketebalan daun pada naungan $65 \%$ lebih tipis $9.90 \%$ daripada daun di bawah naungan $55 \%$.

Warna daun. Sirih merah dan sirih wulung dilakukan dengan mengamati sisi daun bagian atas dan bawah. Berdasarkan Tabel 12, Sirih merah dan Sirih wulung yang tidak dinaungi memiliki warna daun hijau terang pada daun sisi atas dan memiliki warna coklat terang pada sisi bawah daun. Perlakuan tanpa naungan memiliki warna hijau terang pada semua jenis sirih. Sedangkan pada naungan $75 \%$ sirih merah sisi atas daun memiliki warna daun hijau gelap dan sisi bawah daun berwarna merah gelap. Sirih wulung memiliki sisi atas daun yang berwarna hijau keunguan. Sirih hijau dan sirih golden memiliki warna hijau gelap, sedangkam sirih hitam memiliki daun berwarna hijau keunguan.
Tabel 10. Pengaruh naungan dan jenis sirih terhadap ketebalan daun

\begin{tabular}{lc}
\hline Perlakuan & Ketebalan daun $(\mu \mathrm{m})$ \\
\hline Naungan $(\%)$ & 3.56 \\
$0-25$ & 2.43 \\
$0-55$ & $5.74 *$ \\
$0-75$ & 2.01 \\
$25-55$ & 1.98 \\
$25-75$ & 1.78 \\
$55-75$ & \\
Jenis Sirih & 2.56 \\
Merah - Wulung & 2.38 \\
Merah - Hijau & 2.34 \\
Merah - Golden & 3.03 \\
Merah - Hitam & 2.34 \\
Wulung - Hijau & 2.36 \\
Wulung - Golden & 2.67 \\
Wulung - Hitam & 2.03 \\
Hijau - Golden & 2.43 \\
Hijau - Hitam & 2.51 \\
Golden - Hitam & \\
Keterangan: angka - angka pada kolom yang dikuti dengan \\
\multicolumn{2}{c}{ tanda * menunjukkan perbedaan signifikan } \\
pada taraf 5\% uji t-student
\end{tabular}

Tabel 11. Interaksi naungan dan jenis sirih terhadap warna daun

\begin{tabular}{|c|c|c|c|c|c|}
\hline \multirow{2}{*}{\multicolumn{2}{|c|}{ Perlakuan }} & \multicolumn{4}{|c|}{ Umur tanaman } \\
\hline & & $9 \mathrm{MST}$ & $10 \mathrm{MST}$ & $11 \mathrm{MST}$ & $12 \mathrm{MST}$ \\
\hline \multirow[t]{5}{*}{$0 \%$} & Merah & $2 / \mathrm{e}$ & $2 / \mathrm{e}$ & $2 / \mathrm{e}$ & $2 / \mathrm{e}$ \\
\hline & Wulung & $2 / \mathrm{e}$ & $2 / \mathrm{e}$ & $2 / \mathrm{e}$ & $2 / \mathrm{e}$ \\
\hline & Hijau & 2 & 2 & 2 & 2 \\
\hline & Golden & 2 & 2 & 2 & 2 \\
\hline & Hitam & 3 & 3 & 2 & 2 \\
\hline \multirow[t]{5}{*}{$25 \%$} & Merah & $3 / d$ & $3 / d$ & $3 / d$ & $3 / d$ \\
\hline & Wulung & $3 / d$ & $3 / d$ & $3 / d$ & $3 / d$ \\
\hline & Hijau & 2 & 2 & 2 & 2 \\
\hline & Golden & 2 & 2 & 2 & 2 \\
\hline & Hitam & 4 & 4 & 4 & 4 \\
\hline \multirow[t]{5}{*}{$55 \%$} & Merah & $4 / b$ & $4 / b$ & $4 / b$ & $4 / b$ \\
\hline & Wulung & $4 / b$ & $4 / b$ & $4 / b$ & $4 / b$ \\
\hline & Hijau & 3 & 3 & 3 & 3 \\
\hline & Golden & 3 & 3 & 3 & 3 \\
\hline & Hitam & 4 & 4 & 4 & 4 \\
\hline \multirow[t]{5}{*}{$75 \%$} & Merah & $4 / \mathrm{c}$ & $4 / \mathrm{c}$ & $4 / \mathrm{c}$ & $4 / \mathrm{c}$ \\
\hline & Wulung & $5 / \mathrm{c}$ & $5 / \mathrm{c}$ & $5 / \mathrm{c}$ & $5 / \mathrm{c}$ \\
\hline & Hijau & 4 & 4 & 4 & 4 \\
\hline & Golden & 4 & 4 & 4 & 4 \\
\hline & Hitam & 5 & 5 & 5 & 5 \\
\hline \multicolumn{6}{|c|}{$\begin{array}{ll}\text { Keterangan: } & \text { 1=hijau muda } 2=\text { hijau terang } 3=\text { hijau } 4=\text { hijau } \\
& \text { gelap } 5=\text { hijau keunguan an }=\text { merah terang } \\
& \text { b=merah, c=merah gelap } d=\text { merah kecoklatan } \\
& \text { e=coklat terang }\end{array}$} \\
\hline
\end{tabular}




\section{KESIMPULAN}

Tanaman sirih yang ditanam dibawah naungan sampai dengan taraf naungan $75 \%$ menunjukkan pertumbuhan (tinggi tanaman, jumlah daun, dan diameter batang) yang lebih baik dibandingkan dengan tanpa naungan. Tanaman sirih yang ditanam dibawah naungan menunjukkan daun yang lebih tipis dengan jumlah klorofil total meningkat, dan kerapatan stomata yang beragam antar jenis. Semua jenis sirih tidak mengandung alkaloid, sedangkan semua jenis sirih mengandung phenol hidrokuinon, flavonoid, tanin, saponin, steroid, dan triterpenoid dengan kuantitas yang berbeda.

\section{DAFTAR PUSTAKA}

Ahmad, U. 2003. Sejarah Keraton Yogyakarta. [Internet]. [diunduh $2014 \mathrm{Feb}$ 26]. Tersedia pada:http://www.sejarahkeratonyogyakarta. co.id.

Azmy, H.J. 2002. Dampak konservasi dan konservasi lahan hutan terhadap kehidupan [komunikasi singkat]. Bul Leuser 4(11) : 21-22.

[DEPKES] Departemen Kesehatan. 2009. Nilai Perdagangan Jamu di Indonesia Rp 4 trilyun per tahun. [Internet]. [diunduh 2013 Sep 11]. Tersedia pada: http://www.depkes. co.id.

Ekawati, R. 2009. Pengaruh naungan tegakan pohon terhadap pertumbuhan dan produktivitas beberapa tanaman sayuran indigenous [Skripsi]. Bogor (ID) Institut Pertanian Bogor.

Gardner, F.P., Pearce, R.B, Mitchell, R.L. 1991. Fisiologi Tanaman Budidaya. Jilid pertama. Herawati Susilo, penerjemah. Jakarta (ID): UI Pr.

Goldsworthy, P.R., Fisher, N.M. 1992. Fisiologi Tanaman Budidaya Tropik. Tohari, Penerjemah. Yogyakarta (ID) : Gadjah Mada University Press. Terjemahan dari : The Physiology of Tropical Field Crops.

Johnson, H.B. 1975. Plant pubescene: an Ecological Perspektive. The Botanical Review vol. 41. New York (US): The New York Botanical Garden.
Jumin, H. B. 1992. Ekologi Tanaman. Jakarta (ID): Rajawali Pers.

Lakitan, B. 2008. Dasar-Dasar Fisiologi Tumbuhan. Edisi 1. Jakarta (ID): PT Raja Grafindo Persada.

Muhuria, L., Tyas, K., Khumaida, N. Trikoesoemaningtyas, Sopandie, D. 2006. Adaptasi tanaman kedelai terhadap intensitas cahaya rendah: karakter daun untuk efisiensi penangkapan cahaya. Bul.agron 34(3):133-140.

Musyarofah, N., Susanto, S., Aziz, S.A., Kartosoewarno, S. 2007. Respon tanaman pegagan (Cantella asiatica L. urban) terhadap pemberian pupuk alami dibawah naungan. Bul. Agron. 35(3):217-224.

Rachmawaty, R.A. 2005. Pengaruh naungan dan jenis pegagan terhadap pertumbuhan, produksi dan kandungan triterpenoidnya sebagai bahan obat. [tesis]. Bogor (ID): Sekolah Pasca Sarjana. IPB.

Riyadi, K.H.S. 1999. Toleransi Beberapa Varietas Padi Gogo (Oryza sativa L.) Terhadap Defisit Cahaya Dan Perbedaan Kadar Sukrosa Pada Daun [Skripsi]. Bogor (ID) Institut Pertanian Bogor.

Salisbury, M.B., Ross, C.W. 1995. Fisiologi Tumbuhan. Jilid 3. DR Lukman dan Sunaryomno, Penerjemah. Bandung (ID) : ITB. Terjemahan dari: Plant Physiology.

Sampoerno, H. 1999. Pengembangan dan pemanfaatan tumbuhan obat Indonesia. Paper Presented at The National Seminar on Medicinal Plants From Indonesia Tropical Forest. 28 April 1999. Bogor, Indonesia.

Sri, H. 2010. Pengaruh naungan yang berbeda terhadap jumlah stomata dan ukuran porus stomata daun Zephyranthes Rosea Lindl [komunikasi singkat]. Bul Anatomi dan Fisologi 18(1).

Sudewo, B. 2005. Basmi Penyakit dengan Sirih Merah. Jakarta (ID): Agromedia Pustaka.

Sundari, $\quad$ T., $\quad$ Soemartono, Tohari, Mangoendidjojo, W. 2008. Anatomi daun kacang hijau genotipe toleran dan sensitif naungan. Bul. Agron. 36(3): 221-228. 
Tarun, A, Rachan., S., Amar, D. S., Imran, W., Ankita, G. 2012. Comparative analysis of antibacterial activity of four Piper betel varieties. Pelagia research library 3(2): 698-705.
Tri, H. 2011. Pemanfaatan Tumbuhan Sirih sirihan (Piperaceae) Dan Palem - paleman (Aracaceae) Dalam Kehidupan Masyarakat Melayu Di Kecamatan Tanjung Tiram Kabupaten Batubara [Skripsi]. Sumatera Utara (ID): Universitas Sumatera Utara. 